\title{
Niche experiments with alternative powertrain technologies: The case of electric city-buses in Europe
}

Benny Borghei and Thomas Magnusson

The self-archived postprint version of this journal article is available at Linköping University Institutional Repository (DiVA):

http:// urn.kb.se/ resolve?urn=urn:nbn:se:liu:diva-141574

N.B.: When citing this work, cite the original publication.

Borghei, B., Magnusson, T., (2016), Niche experiments with alternative powertrain technologies:: The case of electric city-buses in Europe, International J ournal of Automotive Technology and Management, 16(3), 274-300. https:/ / doi.org/ 10.1504/IJATM.2016.080787

Original publication available at:

https:// doi.org/ 10.1504/IJ ATM.2016.080787

Copyright: Inderscience

http:// www.inderscience.com/ 


\title{
Niche experiments with alternative powertrain technologies The case of electric city-buses in Europe
}

\author{
Benny (Behbood) Borghei*, Thomas Magnusson \\ Department of Management \& Engineering \\ Linköping University, SE-58183 Sweden
}

\begin{abstract}
Using sociotechnical transitions literature, this paper analyses the early market introduction of electric city-buses in Europe. It identifies the role of bus manufacturers and their corresponding choices of alternative powertrain and charging technologies. Study results contrast the traditional dichotomy of incumbents versus niche actors and questions perceived role of incumbents as a homogenous group of actors. The paper proposes an alternative to the typical perception of industry incumbents as the guardians of the current sociotechnical regime, suggesting that a strong position in the established regime may actually facilitate introduction of radical technological solutions. The paper invites transition scholars to make more detailed analyses of actors' constellations and it further suggests that policy makers need to pay attention to the diversity of individual actors' strategies.
\end{abstract}

\section{Keywords:}

Multilevel perspective (MLP), Strategic Niche Management (SNM), Niche-regime interactions, Field configuring events (FCEs), Actors, Translation

\footnotetext{
*Corresponding author: Behbood.Borghei@liu.se
} 


\section{Introduction}

The amount of $\mathrm{CO}_{2}$ emissions from heavy commercial vehicles (trucks and buses) increased by $36 \%$ between 1990 and 2010. Heavy vehicles now correspond to a quarter of the total $\mathrm{CO}_{2}$ emissions from road transportation in Europe (European Commission, 2014). While it is becoming increasingly clear that conventional technologies have to be replaced by new or alternative technologies in order to cut down $\mathrm{CO}_{2}$ emissions, demanding requirements for reliability, performance and uptime make actors hesitant towards adopting new technologies. In spite of these restrictions however, the European heavy vehicles sector has recently witnessed early signs of a significant technological renewal in a particular area of application, namely city-buses. The specific characteristics of city-bus operations makes this different from most of other heavy vehicle applications, which in turn allows for implementation of new powertrain technologies. In particular, the short distance travel and relatively low speed driving cycles combined with frequent stop-starts in dense traffic areas, provide significant potentials for improved energy efficiency and reduced $\mathrm{CO}_{2}$ emissions by means of electrification (c.f. CIVITAS, 2015a, 2015b, 2010). Life-cycle assessments indicate that efficiency gains and reduced $\mathrm{CO}_{2}$ emissions could be possible even in countries like China, where a large percentage of the electricity is based on coal (Ou et al., 2010). However, other assessments suggest that $\mathrm{CO}_{2}$ reduction depends on the use of a higher percentage of electricity from nuclear, natural gas or renewables; an electric power mix which is more akin to the European conditions. Furthermore, due to the resource consuming extraction processes of materials for battery production, choices regarding battery size will have a significant influence on the lifecycle environmental impacts of electric buses (Cooney et al., 2013).

Potential efficiency gains together with the image of a clean, silent and eco-friendly transport solution have resulted in several pilot projects and public demonstrations of electric city-buses across Europe (c.f. UITP, 2015). However, if these projects remain as isolated local experiments, they will suffer from lack of expertise and limited implementation experience. Moreover, the innovative solutions will be more expensive than vehicles using conventional mass-produced diesel engines. Therefore, there is a risk that a further implementation beyond the initial pilot projects cannot be justified. The learning experiences will thus be limited and this will result in a vicious circle. Whereas technological variety can be considered advantageous from an evolutionary perspective (Kemp et al., 2001; Garud et al., 2010; Garud and Karnoe, 2001), it is also problematic in terms of unresolved uncertainties and limited possibilities for economies of scale (Chanaron and Teske, 2007).

To address these problems, literature on socio-technical transitions and strategic niche management suggest that policy makers should facilitate networking and visioning, thus enabling translation of local experiences into generally applicable practices, routines and standards (Smith, 2007). The instance of such translation assumes that there are industry actors who will take a role as translators, thus promoting a broader industry-wide adoption of new technologies. Recent studies have shown that solid understanding of established practices, routines and standards within the existing regime is a prerequisite to be able to take this role (Bakker et al., 2015; Berggren et al., 2015; Elzen et al., 2012; Smink et al., 2015). Hence, translators build their legitimacy not only on participation in various local activities, but also on their existing position in the industry. 
Using concepts derived from literature on socio-technical transitions and strategic niche management, this paper presents a policy-oriented analysis of the early market introduction of electric city-buses in Europe. The paper identifies the different bus manufacturers involved and classifies them according to their current industry positions. It further discuss how these positions influence technology choices.

The rest of the paper is organized as following: the next section lays down the foundational concepts on sociotechnical transitions literature and strategic niche management. The paper also covers recent advancements in relation to the inclusion of spatial dimension into transition theories and in particular the emergence of the concept of field configuring events. The theoretical framework is then linked to the methodology which is presented in Section 3. The subsequent Section 4 introduces the European city bus industry and the context in which it operates. This section also presents a number of technological alternatives related to the electrification of city-buses. Section 5 provides an overview of European electric bus manufacturers and their technological choices and Section 6 contrasts the case study findings with the theoretical framework. This is followed by conclusions and policy implications in Section 7 . 


\section{Theoretical framework}

\subsection{Multilevel perspective: a framework to analyze system transitions}

Change is a major concern in large sociotechnical systems as it requires alteration and re-alignment of the existing industry configurations not only in terms of core technological components, but also in terms of infrastructural networks as well as the fabric of the society in which those systems are embedded in (Hughes, 2005). In this respect, the sociotechnical transitions literature has called for coherent public policies to stimulate system-wide changes towards more sustainable alternatives (Kemp, 1994; Kemp et al., 1998; Rip and Kemp, 1998; Rotmans et al., 2001). In particular, the development of the multilevel perspective (MLP) has been helpful to construct an integrative framework on the dynamics of transitions across several layers of structuration (Rotmans et al., 2001; Geels, 2002; Elzen et al., 2004; Geels, 2005). From this perspective, transitions come about as a result of interactive processes that take place across and within multiple levels (Geels and Schot, 2007, p. 400). The MLP framework considers sociotechnical transitions as the outcome of reciprocal interactions across three nested levels: micro-level (technological niches), mesolevel (sociotechnical regimes) and macro-level (landscape developments).

\section{FIGUIRE 1 HERE}

As shown in figure 1, the sociotechnical regime is at the heart of the MLP framework. This is where industry incumbents operate based on established technologies and infrastructure, as well as existing networks and cognitive rules that are clearly set out (Geels, 2005, 2004a). Technological innovations are thus incremental and often within the already established boundaries of the sociotechnical regime. Total market size is relatively stable and the share of incumbents is to some extent predefined based on their position within the established sociotechnical regime. Moreover, entry barriers are quite high and it is very difficult for newcomers to break-in as they lack resources, legacies, reputation, customers' loyalty as well as adequate sales channels, after sales services, maintenance and supply networks. These are all important determining criteria for performing at the regime level (Geels, 2004b, 2005, 2010). This is indicated by higher levels of structuration alongside the vertical dimension of the MLP framework. 
Nevertheless, the sociotechnical regime is also exposed to different kinds of pressure, stemming from landscape developments such as changing fuel prices, environmental issues, general demographic and macro socio-economic trends or crises, as well as parallel developments at the niche level. Occasionally, accumulated landscape forces may result in sociotechnical regimes to break apart or to partly open up for niche technological innovations to get in and diffuse. The technological niche concept should not be confused with market niche concept, which is prevalent in marketing literature to describe a narrow market segment for sales. In the MLP framework it rather refers to 'safe havens' for fledgling technologies to get matured through experimentation and small scale launch and demonstrations (Kemp et al., 1998; Geels, 2002). In contrast to the established regime, the technological niche level is associated with lower degrees of structuration, which means that there are fewer rules and less strict criteria for performance. As a result, there are more freedom for trial and error with new technologies and greater possibilities to open up for radical innovations (Geels, 2002). Moreover, as the entry/exit barriers are relatively low, many new actors tend to enter and then shakeout over the time; many initiatives simply fail due to inferior design or limited application, or due to technological hype cycles (Verbong et al., 2008; Ruef and Markard, 2010; Bakker, 2010; Konrad et al., 2012; Bakker and Budde, 2012). Because of the lower degree of structure, uncertainties prevail and activities often have a relatively short lifetime at this level. Thus, actors need to put in great efforts and resources to uphold niche technological innovations. This makes it difficult for newly established firms with limited resources to become competitive and many of them fail to make it to the mainstream market. For this reason, transition scholars have pointed out to the need for strategic niche management (SNM) as a tool for initiating, protecting and nurturing radical innovations (Hoogma et al., 2002, 2004; Kemp et al., 1998; Schot and Geels, 2008).

\subsection{Transitions require coordinated interactions}

Single experiments do not result in significant systemic changes, since they are often isolated local projects which are not only disconnected from the real world, but also very place specific (i.e. context-dependent). Studies of strategic niche management suggest that, for niche technological innovations to become more competitive, various internal processes across local levels should be linked together and to higher structural orders. This is what transition scholars call the global niche concept (Geels and Raven, 2006). It refers to the formation of an emerging institutional field or proto-regime and emphasizes the exchange of knowledge and experience among actors, user-groups and industry-platforms to transcend niche technological innovations beyond local contexts. Local to global niche coordination requires dedicated work and aggregation processes such as selection, comparison, framing, contestation and interpretation of local lessons (Verbong et al., 2008). Likewise, global to local niche adaptation is not considered as a linear and straightforward process, but rather involves (re)negotiation of expectations and interests aimed at translating global guidelines into locally-applicable arrangements (2008, pp. 131149). 
When it comes to the niche and regime level interactions, recent theoretical advancements suggest two alternative processes (Smith and Raven, 2012):

1) Fit-and-conform which encourages niche technological innovations to adapt (fit) to the exiting performance criteria and conform to the established selection environment that is prevailing at the current sociotechnical regime

2) Stretch-and-transform which undermines performance criteria of the existing sociotechnical regime and encourages niche actors to stretch and influence current practices through institutional reforms (transform), resulting in new selection environment that would be more in favor of niche technological innovations.

Both processes have their own advantages and drawbacks. On the one hand, the fitand-conform process may easily hamper potential benefits of radical niche innovations due to compliance with current selection environment. On the other hand, stretch-andtransform would run the risk of protectionism or establishing new performance criteria in favor of poor technologies (c.f. Hommels et al., 2007). However, these two processes are not necessarily mutually-exclusive. For instance, while price-performance for niche innovations is improving, the selection environment at the regime level can be also adjusted so that it could better accommodate novel technologies. But in either case, there is a need for a common place where the desired performance criteria and selection processes can be discussed, negotiated and translated (Raven et al., 2011, 2008; Smith, 2007).

\subsection{Recent advancements in transition literature}

Having described the challenges of local-global adaptations, there is a need for an open environment or public sphere where translations, negotiations and adaptations from different levels of structuration can be interacted. This is in line with earlier theoretical concepts such as arenas of development where heterogeneous actors regardless of their geographic or structural position may engage in the development processes of new technologies, interpreting the context and carrying out interventions (Jorgensen and Sorensen, 1999; Jørgensen, 2012). From this perspective, conflicts are considered as an important element of change by helping actors to navigate through a more pluralistic environment where different solutions are put into reality test and their weaknesses and strengths become more visible (ibid).

Engaging actors from various contexts and different geographical locations also opens up another crucial aspect raised by scholars mostly from economic geography, urban studies and related disciplines who have called for more attention to a spatial dimension in sociotechnical transitions (Coenen et al., 2010, 2012; Truffer and Coenen, 2012; Markard et al., 2012). These scholars have also criticized the abovementioned notion of 'localglobal' as being spatially naïve since these terms hold specific geographic meanings in those disciplines, but in transition literature still reside on an abstract level without explicit spatial connotations (Bridge et al., 2013; Hansen and Coenen, 2015). Responding to these critiques, transition scholars have recently taken into account the spatial dimension as an 
important empirical aspect of their studies on sociotechnical transitions. One of such examples is the study of bus rapid transit systems (BRT) by Sengers and Raven (2015), in which place-specific characteristics including local politics proved to be influential in causing both challenges and opportunities in the process of transitioning. They showed how very similar BRT technology could turn into a successful experience in the city of Bogotá in Columbia, or otherwise turn out to be a failure in the case of Bangkok in Thailand.

Inclusion of spatial dimension has also contributed to further enrichment of transition literature by adding new theoretical concepts such as field-configuring events (FCEs). The grounding motivation for FCEs and similar concepts in transition literature is that actors are usually confined within their primary geographic boundaries or within their main areas of operation. Thus, it is usually difficult to find adequate knowledge outside their existing networks or outside their core areas of expertise. To overcome this problem, they have to establish linkages over distant cognitive and geographic space in order to gain access to new information about markets, technologies, and practices elsewhere (Möllering, 2010). Therefore, they may benefit from specific arrangements in which diverse range of actors come together and engage in intensive interactions and exchange of ideas and information over a short period of time through field configuring events (Lampel and Meyer, 2008; Meyer et al., 2005). International exhibitions or trade fairs are typical examples of temporary co-presence of actors from across the globe under the same roof. This enables face to face interaction and exchange of ideas as well as expansion of networks among participants (Bathelt et al., 2004; Bathelt and Schuldt, 2010; Schuldt and Bathelt, 2011). Industry summits, policy sessions or strategic roadmap meetings are also temporary spaces where key actors are gathered to shape or influence the future direction of particular sectors of economy (Lampel and Meyer, 2008; Hardy and Maguire, 2010; Jolly and Raven, 2016; Henn and Bathelt, 2015). Field configuring events are particularly important in the face of uncertainty conditions by bringing in the otherwise disparate actors to engage in coordinated actions towards future development of certain technological fields, creation of new markets or formation of new industries. These new theoretical developments have largely shaped our research design which is further discussed in the methodology section. 


\section{Methodology}

\subsection{Case characteristics}

A prime challenge in terms of research design was related to the real-time and somewhat fragmented character of the case (i.e. the early introduction of electric city buses in Europe). The reason is that, existing theories on sociotechnical transitions are primarily based on ex-post analyses of historical events, where the outcome is already known to the researcher. But here the main challenge is to study potential transition processes in the making, and thus being surrounded by the case developments in its live conditions. This makes the study more similar to ethnographic enquiry where the researcher explores a particular phenomenon as it evolves, trying to unveil complexities by describing it in an elaborated manner (Barnard and Spencer, 1996). In particular, the case study focused on bus manufacturers' activities related to early market introduction, as opposed to firm internal $\mathrm{R} \& \mathrm{D}$ activities. This is because recent advancements in transition theories tend to emphasize the need for open environments to enable processes of translation, negotiation and adaptation. To gain legitimacy in the society, the new technology thus has to be introduced to and tested in a public sphere. The empirical studies revolved around a few critical field-configuring events specifically related to the development of alternative powertrain technologies for urban transportation and in particular city buses in Europe.

\subsection{Data sources}

Three main sources of primary data have been used in this study: 1) Field-configuring events such as international trade fairs, exhibitions and conferences related to public transportation and heavy commercial vehicles including trucks, buses, coaches and city buses 2) Field visits to several electric bus demonstration projects at different cities in Europe, and 3) Semi-structured interviews with representatives of bus manufactures and public transport authorities. Observations at field-configuring events and electric bus demonstrations were particularly important because they provided opportunities for direct access through spontaneous contact and often dedicated interviews with representatives of bus manufacturers and public transport authorities (PTAs). Nevertheless, we have been aware of the differences between our ethnographic observations versus interview data collection (Denzin and Lincoln, 2012; Creswell, 2006; Kunda, 2009). Hence we rather saw this as a vantage point for combining different sources of qualitative data. Field notes and interview summaries have been compiled together in the form of empirical reports or brief internal audit trails (Lincoln and Guba, 1985; Schwandt and Halpern, 1988). Table 1 summarizes primary sources of data.

\section{TABLE 1 HERE!}




\section{TABLE 1 CONTINUED HERE}

The table specifies details of the main categories of primary empirical data used in this paper. In particular, visits to three international field configuring events during the period 2014-2015 were useful to get a broad overview of the development of powertrain technologies for heavy vehicles in Europe. These included visits to the largest international exhibition for commercial vehicles in Europe (IAA-2014), and the largest public transport congress and exhibition in the world (UITP-2015) as well as the largest bus exhibition and conference in Europe (Busworld-2015). It was further complemented with attending another two field configuring events with specific focus on electric powertrain technologies for city buses in the Nordic region including Transportforum-2016 and Nordic Electric Bus Initiative conference in 2015. The primary advantage with those events was that they included dedicated conference tracks and panel sessions on electrified public transport and provided deeper insights to the latest advancements in technological alternatives and experiences from recent test results and demonstrations. Additional insights were gained though visits to electric bus demonstration sites in Hamburg, Umeå and Gothenburg.

Furthermore, we have been interested in obtaining an overall understanding of major supply and demand markets for electric buses in Europe. For this reason, we considered Germany as an important market due to its sheer size and the corresponding demand for public transportation in its major cities. Germany is one of the three largest national markets for city buses in Western Europe and it is also the leading automotive and bus manufacturing economy. The German government supports development and diffusion of electric vehicles forcefully through direct public subsidies and other policy initiatives. An internet-based survey of electric bus demonstration projects in Germany was done during April-June 2015 by a native master's student as part of his Studienarbeit (work-study) research project under our supervision at Linköping University (Ludwig, 2015).

Moreover, to gain insights about ongoing electric bus demonstrations across Europe we made an interview with a representative from ZeEUS project (Zero Emission Urban bus Systems), which is coordinated by the International Association of Public Transport (UITP). The ZeEUS project gathers data on stakeholders involved in ongoing field tests of electric buses, including public transport authorities and operators, charging equipment suppliers, energy companies, research centers and consultancies. Among other actors, six bus manufacturers take part in the project demonstrating electric buses in ten different cities situated in nine countries in Europe. The project runs from November 2013 to April 2017 with the aim of testing and evaluating a number of different powertrain technologies and charging solutions for electric city buses (ZeEUS, 2016) 
However, an important aspect of doing research about alternative powertrain technologies in the automotive industry is to avoid falling into the glories of technological hypes which are still immature and tend to fadeout over the time or those that require a long period of time to become available as fully functioning vehicles in the market (Bakker, 2010; Bakker and Budde, 2012). We have been aware of such trends and wanted to make sure that technology demonstrations at the exhibitions were not just prototype samples or mock-ups, but rather vehicles that could be delivered to customers. Therefore, we specifically asked company representatives if their new vehicle technologies are yet - or soon become - available in the market. Furthermore, we crosschecked statements by bus manufacturers with publicly available data sheets and public announcements, media sources, and published research data, as well as information gained at our field visits and interviews with other stakeholders.

\subsection{Case analysis}

The case analysis relied on a pattern-matching technique (Yin, 2013) contrasting empirical data with theory. One important aspect of the analysis was to identify different bus manufacturers and apprehend their distinctive role in the early market introduction of electric buses in Europe. Following theoretical insights from transition theories, we were able to make a representation of our empirical data according to the three levels of MLP framework. Propositions based on literature on socio-technical transitions and strategic niche management guided our subsequent discussion on the role of manufacturers involved and their choices in terms of alternative powertrain technologies. 


\section{European city buses and multilevel sociotechnical developments}

\subsection{Increasing pressures at the landscape level}

One of the most important developments at the landscape level is the urbanization trend in general, and the increasing demand for sustainable city transportation in particular. Statistics show that around half of the world population lived in cities by the turn of the millennium, while in Europe and other advanced economies urban population had already surpassed $65 \%$ in most areas (GMR, 2013). The urbanization is likely to reach as high as $75 \%$ by 2025 and $85 \%$ by 2050 in Europe (UNEP, 2009). According to a recent survey, there will be a threefold increase in the total areas for urbanized land between 2000 and 2030 (Seto, Güneralp et al. 2012 van Audenhove, Korniichuk et al. 2014 in Rode et al., 2014). Urban traffic is increasingly taking a larger share of total distance travelled around the world. More than $60 \%$ of all kilometers travelled today are within urban areas and the total amount of urban travel is also expected to be tripled by 2050 (Van Audenhove et al., 2014, p. 6).

The increasing need for urban transport means that $\mathrm{CO}_{2}$-emissions from urban traffic will continue to rise (Rode et al., 2014, p. 3). However, the problem of urban traffic is not merely limited to $\mathrm{CO}_{2}$ and GHG emissions. In many large cities, traffic is associated with significant problems of local air quality, noise and congestion. To address these problems a shift from private vehicles to public transportation is essential. At the same time it is also necessary to overcome air pollution and noise from public transport vehicles. The International Association of Public Transport (UITP) has highlighted a number of priority areas where actions are urgently needed. Among main areas of action for UITP is the shift from private to public transport by doubling the market share of public transportation until 2050. The estimated savings are around 170 million tons of oil and 550 million tons of $\mathrm{CO}_{2}$ equivalent as well as $15 \%$ reduction in urban traffic fatalities (UITP-PTx2, 2014).

\subsection{The existing sociotechnical regime}

City buses should be analyzed as part of the overall structuring of the established automotive industry, which can be generally broken down into private and commercial vehicles. One of the main characteristics of commercial vehicles is the presence of the diesel combustion engine as the dominant powertrain technology. This technology has been preferred due to the need for power, reliability and robustness, which have been (and still is being) achieved with incremental improvements and further enhancements throughout the past few decades. As figure 2 shows, commercial vehicles can be further broken down into goods transport (i.e. trucks and trailers) and passenger transport (i.e. buses and coaches) as well as construction vehicles and other specific applications (e.g. refuse trucks, mobile cranes and fire-fighting vehicles, etc.). 


\section{FIGUIRE 2 HERE}

In terms of demand, the European bus market is quite mature and - with the exception of the 2008-09 financial crisis - relatively stable with an average sales of 35,000-45,000 new vehicles per year (ACEA Registration Figures, 2015). This is about 10\% of the total heavy commercial vehicle sales in Europe. City buses and coaches share engines and powertrain technologies with heavy goods transport vehicles (trucks). However, the design of city bus bodies and interiors is highly customized. In most cases, city buses are produced based on public procurement orders which demand adaptations to the specific urban environment. Being heavily influenced by urban requirements and local policies, this results in a very fragmented market with limited potentials for economies of scale. Therefore, throughput in production lines is quite low and labor costs are higher for bus manufacturing than other segments of the automotive industry (Gwosdz et al., 2011).

Incumbent bus manufactures in Europe can be divided into two main categories. The first category consists of integrated bus and trucks manufacturers, which have capabilities to develop and produce both the engine/powertrain and the chassis/body/interior. Six manufacturers belong to this category: Daimler, MAN, Volvo, Scania, Iveco and DAF. These manufacturers have dominated the heavy commercial vehicles for several decades (Borghei and Magnusson, 2016). They have traditionally produced diesel-fueled vehicles based on in-house technologies. By developing engine families that can be shared among different vehicle lines, they leverage synergies across trucks, buses and other types of heavy commercial vehicles. Together these manufacturers capture more than $90 \%$ of the complete sales of heavy commercial vehicles (heavy trucks and buses) in EU-27.

The second category of industry incumbents are the specialized bus manufacturers. These firms design chassis and bodies, and they sometimes assemble parts of the propulsion system and other parts of the vehicle by themselves, but they do not develop or produce their own engines and powertrains. Instead, they source engines from either the first category (the integrated trucks and bus manufacturers), or from independent engine producers outside Europe such as Cummins in the United States. The firms in this category are much smaller than the firms in the first category of incumbents, and the firms are also more diverse. Some firms only serve their national markets, such as Alexander Dennis and Wright Bus in the UK. Others operate more broadly on an international scale, such as Solaris, VDL, van Hool and Irizar. The specialized bus manufacturer category also includes several small firms who operate as contract manufacturers, producing buses which are sold under the brands of the larger manufacturers. 


\subsection{Technological innovation at the niche level}

Currently, electric buses account for only a tiny fraction of total European city bus market and vehicle manufacturers still have to prove that the new technology is capable of meeting performance requirements for everyday operations. Thus, electric-powered buses represent a fundamental step away from the existing dominant design, i.e. the diesel engine bus. A significant novelty is due to the fact that bus operation depends on external charging from electric grids. Hence, efforts to integrate local public transport systems with the existing electric distribution networks are essentially required to facilitate implementation. It thus encounters bus manufacturers with new challenges which requires integration of knowledge from new disciplines as well as collaborations outside their existing domains of operation.

In terms of charging infrastructure, a number of different technological solutions exist, ranging from ordinary plugs for slow charging to fast and ultrafast charging using conductive arms and pantographs, as well as equipment for inductive opportunity charging. Each of these technological solutions have their own advantages and drawbacks.

The slow charge solution often entails overnight charging which in turn requires large battery packs on the part of vehicles to stay in service during the whole day. The advantage is that a few central charging spots can serve a fleet of buses in a similar manner as central fueling depots serve fleets of diesel buses. This reduces the need for extensive infrastructure investments. The bus can be used flexibly on different routes and the range is long, meaning that buses can operate with similar schedule as traditional diesel buses. However, the downsides are high battery costs and significant environmental impacts from extraction of rare-earth materials for battery production. Moreover the excessive weight and size of large battery packs reduces passenger payloads and offsets energy efficiency gains. The extensive time periods required for slow charging also reduces the time that the bus is available for operation i.e. in case they are also used for work night-shifts or needed to be re-charged during the day. Thus a number of reserved buses may be necessary to ensure the same level of transport service availability.

By contrast, fast charging allows for much smaller battery packs. This results in lower vehicle costs and reduced environmental impacts from battery production. Due to lower vehicle weight and size, the passenger payload and overall energy efficiency will be higher. However, the down side in this case is the extensive investments required for establishing fast charging infrastructure. For each charging station, there is a need to investigate various electric grid interconnection considerations as well as city planning issues such as urban design and integration with the built up environment, construction and installations as well as required permits from municipalities and city authorities, etc. Moreover, public transport authorities need to consider the meantime for frequent re-charging when they plan schedules for operation. Consequently, the implementation of fast charged electric buses entails extensive infrastructural considerations as well as changes in vehicle operation schedules. Operation will be restricted to those routes equipped with charging facilities. Here, conductive and inductive options can be both considered as different means of charging. Whereas conductive solutions tend to be the preferred option for end-stations, inductive solutions can provide possibilities for continuous charging alongside designated 
bus routes with least visibility interference in terms of built-up city environment. However at this point in time, conductive charging is more preferred due to maturity, while inductive charging is still being developed specially with regards to safety and potential health concerns such as strong magnetic fields around charging areas.

In terms of powertrain technologies, an important distinction can be made between plug-in hybrids and full electric buses. Plug-in hybrid powertrains in parallel configuration combine electric motors with traditional internal combustion engines. Whereas the electric motor is the main source of motive power, the internal combustion engine assists the electric motor when extra power is needed, such as driving in steep uphill. Moreover, the internal combustion engine can still take over as the main source of motive power if the battery runs out. Hence plugin hybrid electric vehicles are considered as a more flexible option in comparison to full electric vehicles. Even though they are equipped with relatively small battery packs, they can still operate on routes with limited fast-charging facilities, and if needed they may skip charging to catchup with the existing schedule time. Therefore, they impose less stress on the existing public transport services. However, the dual sources of motive power needs to operate smoothly together which means that developing hybrid powertrain technologies (specially in parallel configurations) is a way more complex engineering task than full electric vehicles. For bus manufacturers, this means that more significant R\&D efforts will be required.

In contrast, the full electric bus represents rather simple technological configuration, comprising only one source of motive power. Whereas the battery size largely determines the range of operation, it is possible to extend it by the means of a range extender. This is an add-on module often consisting of an internal combustion engine and a generator, which is used as an on-board battery charger. The interface between the range extender and the electric powertrain is relatively simple (similar to series-hybrid configuration) and the result is a vehicle that is more flexible in terms of operation. Range extenders based on hydrogen fuel cells and other sources of energy have also been presented but still considered as developing technologies with lower readiness for everyday demanding applications (Bakker, 2010; Bakker and Budde, 2012; Konrad et al., 2012). 


\section{Electric buses in Europe}

\subsection{Overview of manufacturers and technologies}

With regards to choices of technology described in the previous section, different bus manufacturers have shown diverse range of interests and technological orientations. Table 2 provides an overview of bus manufacturers who promoted electric city buses at major field configuring events. They are divided into three main categories namely: integrated truck \& bus manufacturers, and specialized bus manufacturers as well as a new group of electric bus manufacturers which we label as newcomers. The table shows powertrain and charging technologies, as well as data provided by the manufacturers on the distance range for operation of the vehicles in pure electric mode.

\section{TABLE 2 HERE!}

Both incumbent bus manufacturers, including integrated truck \& bus manufacturers and specialized bus manufacturers, are present in this table together with a few newcomers. As the table shows, the number of firms in the specialized bus manufacturer category outnumbers both the newcomers and the integrated truck \& bus manufacturers. In terms of charging technology choices and distance range, there are some distinct variations between manufactures. Four of the six specialized bus manufacturers in the table showed an ambition to retain flexibility, being prepared to deliver full electric buses designed either for fast-charging or slow-charging. By contrast, the newcomers are primarily geared towards full electric buses with large battery packs for slow-charging, with the exception of Hybricon, who has introduced full electric buses for fast-charging.

Volvo is the only integrated truck \& bus manufacturer among the six industry incumbents in Europe, who appears in this table. This is also the only firm that currently offers an in-house plug-in hybrid solution in the European market. Volvo has taken a clear stance in favor of fast-charging with a small size battery pack and limited distance range on full electric driving mode. 


\subsection{Newcomers}

The newcomers in the table include two new technology based startups: Ebusco from the Netherlands and Hybricon from Sweden and one entrant from China: BYD, which has established strong foothold in the European market. Other entrants, such as Linkker in Finland, were either in the test and development phase or had difficulties to present fully functional vehicles in the market by the time when the data for this study was collected. BYD has a background as a battery manufacturer and is now one of the leading electric bus manufacturers in China. Electric bus manufacturers in China benefit from strong policy support on an expansive home market. In a recent paper, Altenburg et.al. (2015) note that "The roll-out of electric buses has been impressive, and buses may potentially become a field of competitive specialization in China." (2015, p. 9). BYD signals clear ambitions to expand sales on export markets, including Europe. It has established its European headquarter in the Netherlands and has expressed clear ambitions to serve the European market with full electric buses. It has also been running extensive test and demonstration projects across several European and Nordic cities during the past few years. Since July 2014 it has delivered a fleet of 35 fully electric buses to Schiphol International Airport in Amsterdam. In the UK, BYD has started collaboration with the specialized bus manufacturer Alexander Dennis to provide electric buses to London. The alliance is expected to deliver the single largest fleet of 51 full size electric buses in Europe, to operate in the central Ultra Low Emission Zone (ULEZ) of London.

The Dutch manufacturer, Ebusco has been also running test and trials in different cities in Europe. It sources components from an extensive network of suppliers within and outside Europe and undertakes major task of integrating them into fully operational electric buses. Ebusco was originally emerged as an academic spinoff in 2012 from the HighTech Automotive Campus in Helmond which has strong linkages with corporate R\&D centers in the Netherlands as well as proximity with Technical University of Eindhoven (TU/e) as an important knowledge pool for advanced research and innovation. The company has done a number of demonstration projects in Finland, Norway, Denmark and Germany (Bremen) and is eager to expand its sales in the European market. The company had strong presence in several automotive exhibitions to introduce its new version of fully electric buses called Ebusco 2.0.

The Swedish manufacturer, Hybricon started as a local initiative to provide the city of Umeå with electric transport solutions. The company has implemented a fully operational electric shuttle line, with two buses connecting Umeå airport to the city center since January 2014. It has also received new orders from the municipality to deliver another 8 electric buses, including three 18-meter articulated four-wheel drive suitable for the harsh winters in Northern Sweden. Hybricon prefers the fast-charging option, but the firm has also expressed willingness to supply buses for slow-charging upon request. In an interview a sales representative explained this strategy, saying that some customers may still prefer to buy one single slow-charged bus initially. 


\subsection{Integrated truck \& bus manufacturers}

While Volvo is the only integrated truck \& bus manufacturer in this table, it does not mean that it is the only one capable of introducing electric buses in this category. Both Scania and MAN have recently introduced diesel hybrid buses (without charging from the electric grid) indicating that they should have the requisite capabilities to introduce electric buses as well. However, so far Volvo stands out as the only integrated truck \& bus manufacturer fully committed for the introduction of both plugin hybrid and full electric buses to the market. Volvo introduced their plugin hybrid in 2014, signing orders for delivery of about 50 buses to different European cities this first year. Moreover, the firm has officially announced market introduction of full electric buses in 2017.

In our interview with the former CEO of Volvo Group, he commented on their intentions for the development of hybrid/electric vehicles stating that increased pressures would make energy efficiency and reduced fossil fuel consumption as the main driving forces for this particular technology in the future. Thus, taking the lead in the development would result in business opportunities for the company. In another interview, the manager of Public Affairs at Volvo Bus referred to the significant production and diffusion of electric buses in China, stating that it was important to take the challenge of Chinese newcomers more seriously. Volvo has signaled ambitions to become a leading supplier of electromobility solutions to cities and has taken steps to realize these ambitions by establishing partnerships with suppliers of charging equipment, taking part in working groups for standardization of fast-charging facilitates, and collaborating with public transport authorities and energy providers in the ZeEUS project in order to promote electrification of city buses in Europe and around the world.

\subsection{Specialized bus manufacturers}

Based on the number of firms in this category, the specialized bus manufacturers appear to be the most active category. The firms in this category also offer the most versatile choices for powertrain configurations and charging technologies. For instance, VanHool has already made it clear that they are quite flexible to offer any available solutions to their customers. To make this even more visible, they have developed the ExquiCity concept, a multi propulsion platform for city bus transportation based on a combination of tram and trolley bus design with the possibility to link a wide range of powertrain technologies. Other notable examples are VDL and Solaris, who are prepared to offer buses for both fast- or slow-charging based on customer demand and any specific conditions for city bus operations. Especially the Polish firm Solaris has been keen in the early introduction of hybrid and full electric buses in Europe. The key to enable this strategy was to establish business relationships outside the traditional diesel engine suppliers and in particular with key component suppliers in the electric powertrain segment (Gwosdz et al., 2011, 2016). Nevertheless, the Senior Area Manager at Solaris emphasized in an interview that even though they are now considered as one of the leading producers of electric buses in Europe, production volumes are still limited to occasional orders, which heavily depend on governmental subsidies. 
The Czech manufacturer, Ekova differs from the above-mentioned specialized bus manufacturers with a background as a producer of trolley-buses and trams. Apart from electric buses under their own brand, they also operate as a contract manufacturer, producing bodies for the Swedish start-up firm Hybricon. They source their main powertrain components from German-Czech suppliers including Škoda and Ziehl-Abegg.

The Turkish company Bozankaya has an established position as a manufacturer of trams and trolley buses both in its home market as well as in Germany. The firm also operates as a contract manufacturer, producing chassis for European companies such as MAN and Neoplan. Through the introduction of its electric bus Sileo, the company has made an attempt to establish itself as an electric bus manufacturer on the European market. When it comes to charging technology, the company provides a rather unique solution on the market. It is based on direct high voltage DC charging that uses a fleet-based infrastructure called Dynamic Charge Matrix which enables charging 10 plugin connections across 10 arrays of buses simultaneously i.e. charging up to 100 vehicles at the same time. According to the Bozankaya's senior technician in charge of research and development, this solution is highly advantageous in terms of improved battery management system and increased efficiency due to the direct DC charging of batteries. The downside however, is that due to the unique design of the charging stations, they cannot be shared with vehicles from other manufacturers.

The Spanish bus manufacturer, Irizar introduced its fully electric bus i2e in 2014. The company has chosen rather large battery packs made of Sodium Nickel (SoNick) combined with super-capacitors. Charging is done through standard combo plug and is only available for overnight (slow) charging. Irizar i2e electric bus has been developed in the ZeEUS project and two vehicles have been tested in different cities in Spain including Barcelona, Madrid and San Sebastian.

The observation that specialized bus manufacturers take an active role in the introduction of electric buses also finds support in the actor constellation of ZeEUS project. That is, five of the six manufacturers involved in the ZeEUS project belong to this category (i.e. Alexander Dennis, Solaris, Irizar, VDL and Skoda), only one integrated truck \& bus manufacturer (Volvo) takes part. The survey of electric bus demonstrations in Germany also provided similar evidence to this argument (Ludwig, 2015). The survey identified ongoing electric bus demonstrations in eight different cities in Germany and announcements of planned projects in four additional cities. These projects primarily engaged specialized bus manufacturers. Among these bus manufacturers Solaris was notably the most active, being engaged in demonstration projects across five cities in Germany by the time of the survey. 


\section{Discussion}

\subsection{Incumbents as heterogeneous actors}

Based on theories of sustainability transitions, one can see the increasing landscape pressures not only as tightening environmental requirements, but also as an opportunity by which the prospects of altering the established sociotechnical regime can be facilitated. This can be reached via the introduction of alternative powertrain technologies for city buses and upon successful implementation, further diffusion through the European market. To support this process, there is a need for arenas of development where actors may interact and share their experiences, compare different perspectives on alternative technological choices, and resolve conflicts (Jørgensen, 2012). Current tests and demonstrations of electric buses in various European cities can be seen as a practical example of such arenas of development.

Literature on sustainability transitions further call for the transfer of local experiences into global practices through translation mechanisms as a crucial step to facilitate broader adoption of new technologies at the regime level (Geels and Raven, 2006; Raven et al., 2011). Following (Smith, 2007), such translation mechanism consists of processes that link experiences from the local niche level to the established sociotechnical regime. These processes of horizontal and vertical interaction include interpretation and negotiation of sustainability problems as well as adaptation and alterations to the corresponding contexts. Global arenas of development is where such translations and adaptations can take place. In the case of electric bus developments in Europe, UITP have initiated the ZeEUS project as a joint arena for different stakeholders to compare results from local experiments and translate it to global rules that could be adapted in other contexts. This may open up possibilities for a prosperous interplay and facilitation of shared routines, practices and standards across different niche level experiments.

However, translation mechanisms may not only entail the formation of arenas of development. The instance of translation also requires translators who can interpret results from individual tests and understand possible implications for the development of generally applicable rules. To be able to attain this role, actors need to be able to speak the language of both the niche level as well as that of the established sociotechnical regime level. This role could be taken by the industry incumbents who also engage in the development of new technologies at the niche level (Berggren et al., 2015).

A common understanding in the MLP framework is that industry incumbents act as the conservative guardians of the current sociotechnical regime, whereas newcomers at the niche level are the ones who push for the alteration of established routines (Geels and Schot, 2007). However, our case makes a contrast to the current understanding of the MLP framework. Our observations provided a different scenario in which many industry incumbents are offering alternative powertrain technologies alongside new entrants (see table 2). Moreover, contrary to the standard notion of the MLP framework, not all incumbent manufacturers in the field of European city buses are the same. Incumbents in this particular setting consist of a heterogeneous group of actors offering variety of technological solutions for alternative powertrain in city bus applications. This pluralistic orientation of incumbents and diversity of their interests can be partly explained by their 
differing internal strategies (c.f. Dijk and Kemp, 2010). However in our case, these strategies are better understood with a classification of incumbent actors as integrated truck \& bus manufacturers versus specialized bus manufacturers. Since specialized bus manufacturers do not develop their own engines in-house, they would continue to stay dependent on the limited number of integrated truck \& bus manufacturers in Europe or on other engine suppliers from abroad if they choose to maintain the existing sociotechnical regime based on diesel combustion engine. Moreover, they see the increasing landscape pressures as an opportunity to engage in transformation or reconfiguration of the sociotechnical regime (Geels and Schot, 2007, 2010). Thus, for the specialized bus manufacturers, alternative powertrain technologies open up possibilities to reduce their dependency on diesel engine suppliers. This means that the emergence of a new technological paradigm could result in their access to a wider range of suppliers and powertrain technologies as well as an opportunity to strengthen their position with regards to the increasing landscape pressures at the regime level.

Thus, our case shows that there are crucial dynamics among incumbent actors within the established sociotechnical regime which can further facilitate sustainability transitions if they are properly understood. However, understanding of such dynamics is only achieved when we get away from the perceived notion of incumbents as a homogenous group of actors. Making such distinctions between different kinds of industry incumbents is a necessary step for better comprehension of transition prospects. This distinction entails that, while some incumbents may take the traditional role of defenders for the established sociotechnical regime, another group of incumbents may not necessarily share the same concern. Yet, the position of industry incumbents as translators can be very important for the early diffusion of new technologies from the niche into the regime level. This is because they have a good understanding of the established routines in the sociotechnical regime and its market requirements. Moreover, this group of incumbent actors can make use of their R\&D resources, market channels, established relationships and service networks in the promotion of alternative powertrain technologies.

\subsection{Niche-regime interactions}

Again, based on the current notion of regime-niche interactions proposed by Smith and Raven (2012), industry incumbents should be typically in favor of fit-and-conform strategy which encourages niche technological innovations to adapt (conform) to the existing performance criteria of the established sociotechnical regime. This is due to the perceived role of incumbents as the defenders of the current regime (Geels, 2002, 2005). Based on this line of argument, newcomers would be more likely to support stretch-andtransform strategy, since they have limited (if any) privilege within the existing regime. This means that newcomers would be in favor of significant infrastructural changes and institutional reforms in order to promote new technological solutions.

However, our case observations contrast such typical assumptions for the role of both incumbents and newcomers. This is clearly evident among the incumbent group of specialized bus manufacturers who have introduced electric buses. Such a contradiction is even more remarkable when it comes to the integrated truck \& bus manufacturer Volvo 
who has made it clear that it is in favor of electromobility and is committed to introduce electric powertrain technologies. It also favors the fast-charging option, which is again quite in contrast to the established routines of the existing regime. This technological solution would require significant changes in terms of charging infrastructure and bus operation schedules as well as involvement of new set of actors responsible for issues ranging from urban design and city planning to electric power supply. The specialized bus manufactures such as Solaris, VDL and van Hool tend to remain more flexible, opening up for different technological options depending on customer requests and local conditions.

More interestingly, the newcomers in our case generally prefer the least radical options in terms of requisite infrastructural change and institutional reforms, which is clearly resonated in their choice of slow-charging solutions even at the cost of larger battery packs. Explanations for this strategy can be found on an individual analysis of actors. For instance, it makes sense that the Chinese BYD promotes vehicles with large batteries since it has a background as battery supplier which means that it can easily source its required components internally. However, a more comprehensive explanation which would be also relevant for new startup firms like Ebusco and Hybricon is that customers are hesitant or still not sure to make major changes at this stage. New entrants may also lack required legitimacy to propose bold changes to the current sociotechnical regime. Therefore, a high degree of adaptation to the established routines (i.e. fit-and-conform strategy) makes it easier for newcomers to enter the market.

Smith and Raven (2012) note that the adjustment processes associated with fit-andconform strategy would run the risk of hampering potential benefits of radical technological innovations. In the case of electric buses, where the easily implemented slow-charging option is associated with significant drawbacks both in terms of environmental performance and costs can be considered as the hampering of potentials for radical innovations. Since the use of large battery packs results in more substantial negative impacts from extraction of raw materials and reduced efficiencies, this may backfire on the image of electric buses as an eco-friendly transport option in the future. Moreover, excessive costs related to the large battery packs may prevent further adoption of batteryelectric propulsion altogether. At this point, the total cost of a limited number of vehicles for test and demonstration is still possible to justify since local authorities might be able to source government funding and incentives to promote an environmental image in their cities. However, deployment of such costly and less environmental friendly solutions would be more difficult to justify on a large scale in the future. Therefore, there is a crucial need for proper policy measures to capture the benefits of the new technology. 


\section{Conclusions and policy implications}

A central problem with ongoing socio-technical transitions is that on the one hand, actors are not sure about which technological paths to invest in, since there are great uncertainties about how the ultimate design will turn out in the future. On the other hand, even choosing the most promising design at an early stage would be too costly since industry standards are not established and economies of scale have not reached yet. Thus, many actors remain passive or indecisive as they do not want to risk gambling on temporary technology hypes. Prevailing uncertainties keep cautious actors wait and observe and delay market introduction. Yet, there can be other actors who may act early to influence industry standards and strengthen their position on the market trying to seize opportunities that the new technology may bring for them.

Using concepts derived from literature on socio-technical transitions and strategic niche management, this paper has analyzed the early market introduction of electric city buses in Europe, with a particular focus on bus manufacturers and their technological choices. The analysis challenges the traditional dichotomy of industry incumbents versus niche actors which is prevalent in this literature and calls for more fine-grained analysis of actors and their strategies in transition studies. In particular, our study presents an alternative approach to the current notion of incumbents, suggesting that a strong position in the established regime would make it possible to introduce more radical innovations. Study results suggest that classification of different kinds of incumbent actors could be useful as a means to explain different technological choices and thus better identification of different transition paths when it comes to ongoing transition processes.

When it comes to policy implications, our study results show that there is a need for delicate policies to facilitate sustainable transitioning of established industries. Our recommendation is that policy makers need to be more attentive to the differences that exist among actors whether it be incumbents or niche actors. Such recommendation entails that there is a need for more detailed analysis of actors and their diverging interests in order to provide more comprehensive policies for system-wide transitioning towards sustainable alternatives.

\section{Acknowledgements}

We are grateful for directions and internal review comments on an earlier version of this manuscript by Professor Christian Berggren at the Department of Management \& Engineering in Linköping University as well as comments from two anonymous reviewers. We also acknowledge valuable results from a survey of electric bus initiatives in Germany by Fabian Ludwig as part of his master's work-study research project under our supervision at Linköping University during spring 2015. The funding for this study was provided by The Swedish Governmental Agency for Innovation Systems (VINNOVA) for the project number 2015-03536 entitled: "Vad är en miljöbuss egentligen? En socioteknisk scenariostudie" (Van Audenhove et al. 2014) 


\section{REFERENCES}

ACEA Registration Figures, 2015. European Automobile Manufacturers' Association, Consolidated Registration Figures [WWW Document]. ACEA. URL http://www.acea.be/statistics/tag/category/consolidated-figures (accessed 4.26.16).

Altenburg, T., Schamp, E.W., Chaudhary, A., 2015. The emergence of electromobility: Comparing technological pathways in France, Germany, China and India. Science and Public Policy 0, 1-12. doi:10.1093/scipol/scv054

Bakker, S., 2010. The car industry and the blow-out of the hydrogen hype. Energy Policy 38, 6540-6544.

Bakker, S., Budde, B., 2012. Technological hype and disappointment: lessons from the hydrogen and fuel cell case. Technology Analysis \& Strategic Management 24, 549-563.

Bakker, S., Leguijt, P., van Lente, H., 2015. Niche accumulation and standardization - the case of electric vehicle recharging plugs. Journal of Cleaner Production 94, 155-164. doi:10.1016/j.jclepro.2015.01.069

Barnard, A., Spencer, J., 1996. Encyclopedia of Social and Cultural Anthropology. Taylor \& Francis, Routledge, London.

Bathelt, H., Malmberg, A., Maskell, P., 2004. Clusters and knowledge: local buzz, global pipelines and the process of knowledge creation. Prog Hum Geogr 28, 31-56. doi:10.1191/0309132504ph469oa

Bathelt, H., Schuldt, N., 2010. International Trade Fairs and Global Buzz, Part I: Ecology of Global Buzz. European Planning Studies 18, 1957-1974. doi:10.1080/09654313.2010.515815

Berggren, C., Magnusson, T., Sushandoyo, D., 2015. Transition pathways revisited: Established firms as multi-level actors in the heavy vehicle industry. Research Policy 44, 1017-1028. doi:10.1016/j.respol.2014.11.009

Borghei, B., Magnusson, T., 2016. INSTITUTIONALIZATION OF ENVIRONMENTAL INNOVATION Joint development of standards, technologies and actor networks in the European heavy duty vehicles sector. International Journal of Automotive Technology and Management IJATM (papers in press).

Bridge, G., Bouzarovski, S., Bradshaw, M., Eyre, N., 2013. Geographies of energy transition: Space, place and the low-carbon economy. Energy Policy 53, 331-340. doi:10.1016/j.enpol.2012.10.066

Chanaron, J.-J., Teske, J., 2007. Hybrid vehicles: a temporary step. International Journal of Automotive Technology and Management 7, 268-288. doi:10.1504/IJATM.2007.017061

CIVITAS, 2015a. Implementation Status Report on the efficiency of the installed supercap bank, Civitas Initiative DYN@MO project, Gdynia [WWW Document]. URL http://www.civitas.eu/sites/default/files/d2.4_impl_stat_rep_g2.2_report_on_the_effic iency_of_the_installed_supercap_bank.pdf (accessed 11.23.15).

CIVITAS, 2015b. Energy saving on tramlines, Choppers - a sustainable solution for energy saving on trams, Clean Fuels and Vehicles Project [WWW Document]. URL http://www.civitas.eu/sites/default/files/civitas-case-study-choppers-energy-savingtrams-craiova.pdf (accessed 11.23.15).

CIVITAS, 2010. Implementation status report on pilot project ELAN, Mobilising citizens for vital cities, Grant Agreement No.: ELAN TREN/FP7TR/218954/"ELAN" by Zdeněk Jarolín \& Jan Kopřiva [WWW Document]. URL http://www.civitas.eu/sites/default/files/civitas-casestudy-choppers-energy-saving-trams-craiova.pdf (accessed 11.23.15). 
Coenen, L., Benneworth, P., Truffer, B., 2012. Toward a spatial perspective on sustainability transitions. Research Policy, Special Section on Sustainability Transitions 41, 968-979. doi:10.1016/j.respol.2012.02.014

Coenen, L., Raven, R., Verbong, G., 2010. Local niche experimentation in energy transitions: A theoretical and empirical exploration of proximity advantages and disadvantages. Technology in Society 32, 295-302. doi:10.1016/j.techsoc.2010.10.006

Cooney, G., Hawkins, T.R., Marriott, J., 2013. Life Cycle Assessment of Diesel and Electric Public Transportation Buses. Journal of Industrial Ecology 17, 689-699. doi:10.1111/jiec.12024

Creswell, J.W., 2006. Qualitative Inquiry and Research Design: Choosing Among Five Approaches, 2nd edition. ed. SAGE Publications, Inc, Thousand Oaks.

Denzin, N.K., Lincoln, Y. (Eds.), 2012. Collecting and Interpreting Qualitative Materials, 4th Revised edition edition. ed. SAGE Publications, Inc, Thousand Oaks.

Dijk, M., Kemp, R., 2010. A framework for understanding product market innovation paths emergence of hybrid vehicles as an example. International Journal of Automotive Technology and Management 10, 56-76. doi:10.1504/IJATM.2010.031456

Elzen, B., Geels, F.W., Green, K., 2004. System Innovation and the Transition to Sustainability: Theory, Evidence and Policy. Edward Elgar Publishing, Cheltenham, UK ; Northampton, MA.

Elzen, B., van Mierlo, B., Leeuwis, C., 2012. Anchoring of innovations: Assessing Dutch efforts to harvest energy from glasshouses. Environmental Innovation and Societal Transitions 5, 1-18. doi:10.1016/j.eist.2012.10.006

European Commission, 2014. European Commission, 2014. A Strategy for Reducing Heavy Duty Vehicles' Fuel Consumption and CO2 Emissions (Executive Summary), Document no.: SWD(2014) 159 final, Brussels, 21.5.2014 URL: http://ec.europa.eu/clima/policies/transport/vehicles/heavy/docs/swd_2014_159_en.p df Accessed: 25, 11, 2015.

Garud, R., Karnoe, P. (Eds.), 2001. Path Dependence and Creation. Psychology Press, Mahwah, New Jersey.

Garud, R., Kumaraswamy, A., Karnøe, P., 2010. Path Dependence or Path Creation? Journal of Management Studies 47, 760-774. doi:10.1111/j.1467-6486.2009.00914.x

Geels, F., Raven, R., 2006. Non-linearity and Expectations in Niche-Development Trajectories: Ups and Downs in Dutch Biogas Development (1973-2003). Technology Analysis \& Strategic Management 18, 375-392. doi:10.1080/09537320600777143

Geels, F.W., 2010. Ontologies, socio-technical transitions (to sustainability), and the multi-level perspective. Research Policy, Special Section on Innovation and Sustainability Transitions 39, 495-510. doi:10.1016/j.respol.2010.01.022

Geels, F.W., 2005. Technological Transitions and System Innovations: A Co-evolutionary and Socio-technical Analysis. Edward Elgar Publishing, Cheltenham, UK ; Northampton, MA.

Geels, F.W., 2004a. From sectoral systems of innovation to socio-technical systems: Insights about dynamics and change from sociology and institutional theory. Research Policy 33, 897-920. doi:10.1016/j.respol.2004.01.015

Geels, F.W., 2004b. Understanding system innovations: a critical literature review and a conceptual synthesis, in: In: Elzen, B., Geels, F.W.,Green, K. (Eds.), System Innovation and the Transition to Sustainability: Theory, Evidence and Policy. Edward Elgar Publishing, Cheltenham, UK ; Northampton, MA.

Geels, F.W., 2002. Technological transitions as evolutionary reconfiguration processes: a multilevel perspective and a case-study. Research Policy, NELSON + WINTER + 20 31, 12571274. doi:10.1016/S0048-7333(02)00062-8 
Geels, F.W., Schot, J., 2010. A Typology of Transition Pathways, in: Transitions to Sustainable Development: New Directions in the Study of Long Term Transformative Change. Taylor \& Francis, Routledge, NY.

Geels, F.W., Schot, J., 2007. Typology of sociotechnical transition pathways. Research Policy 36, 399-417. doi:10.1016/j.respol.2007.01.003

GMR, 2013. Global Monitoring Report: Rural-Urban Dynamics and the Millennium Development Goals, A joint publication of the World Bank and the International Monetary Fund, (C) 2013 International Bank for Reconstruction and Development / The World Bank $1818 \mathrm{H}$ Street NW, Washington DC 20433.

Gwosdz, K., Guzik, R., Domanski, B., 2016. European semi-periphery under environmental pressure: the case of urban public bus transportation and private bus-makers in Poland. International Journal of Automotive Technology and Management, Special issue on Comparative policy approaches in the regional development of the low carbon vehicle sector (forthcoming).

Gwosdz, K., Guzik, R., Domanski, B., 2011. Environmental Pressure in the Fragmented Markets: the Fall and Rise of Bus Makers in Poland. European Review of Industrial Economics and Policy No. 3, 15 December 2011.

Hansen, T., Coenen, L., 2015. The geography of sustainability transitions: Review, synthesis and reflections on an emergent research field. Environmental Innovation and Societal Transitions 17, 92-109. doi:10.1016/j.eist.2014.11.001

Hardy, C., Maguire, S., 2010. Discourse, Field-Configuring Events, and Change in Organizations and Institutional Fields: Narratives of DDT and the Stockholm Convention. ACAD MANAGE J 53, 1365-1392. doi:10.5465/AMJ.2010.57318384

Henn, S., Bathelt, H., 2015. Knowledge generation and field reproduction in temporary clusters and the role of business conferences. Geoforum 58, 104-113. doi:10.1016/j.geoforum.2014.10.015

Hommels, A., Peters, P., Bijker, W.E., 2007. Techno therapy or nurtured niches? Technology studies and the evaluation of radical innovations. Research Policy 36, 1088-1099. doi:10.1016/j.respol.2007.04.002

Hoogma, R., Kemp, R., Schot, J., Truffer, B., 2002. Experimenting for Sustainable Transport: The Approach of Strategic Niche Management, 1 edition. ed. Routledge, London; New York.

Hoogma, R., Kemp, Schot, Truffer, 2004. Book reviews: Experimenting for Sustainable Transport: The Approach of Strategic Niche Management. Technology Analysis \& Strategic Management 16, 561-566. doi:10.1080/0953732042000295847

Hughes, T.P., 2005. Human-Built World: How to Think about Technology and Culture. University of Chicago Press, Chicago and London.

Jolly, S., Raven, R.P.J.M., 2016. Field configuring events shaping sustainability transitions? The case of solar PV in India. Technological Forecasting and Social Change 103, 324-333. doi:10.1016/j.techfore.2015.08.015

Jørgensen, U., 2012. Mapping and navigating transitions-The multi-level perspective compared with arenas of development. Research Policy, Special Section on Sustainability Transitions 41, 996-1010. doi:10.1016/j.respol.2012.03.001

Jorgensen, U., Sorensen, O.H., 1999. Arenas of Development - A Space Populated by Actorworlds, Artefacts, and Surprises. Technology Analysis \& Strategic Management 11, 409429. doi:10.1080/095373299107438

Kemp, R., 1994. Technology and the transition to environmental sustainability: The problem of technological regime shifts. Futures 26, 1023-1046. doi:10.1016/0016-3287(94)90071-X 
Kemp, R.P.M., Rip, A., Schot, J.W., 2001. Constructing Transition Paths Through the Management of Niches, in: Garud, R., Karnoe, P. (Eds.), Path Dependence and Creation. Lawrence Erlbaum, Mahwa (N.J.) and London, pp. 269-299.

Kemp, R., Schot, J., Hoogma, R., 1998. Regime shifts to sustainability through processes of niche formation: The approach of strategic niche management. Technology Analysis \& Strategic Management 10, 175-198. doi:10.1080/09537329808524310

Konrad, K., Markard, J., Ruef, A., Truffer, B., 2012. Strategic responses to fuel cell hype and disappointment. Technological Forecasting and Social Change, Contains Special Section: Actors, Strategies and Resources in Sustainability Transitions 79, 1084-1098. doi:10.1016/j.techfore.2011.09.008

Kunda, G., 2009. Engineering Culture: Control and Commitment in a High-Tech Corporation. Temple University Press, Philadelphia.

Lampel, J., Meyer, A.D., 2008. Field-Configuring Events as Structuring Mechanisms: How Conferences, Ceremonies, and Trade Shows Constitute New Technologies, Industries, and Markets. Journal of Management Studies 45, 1025-1035. doi:10.1111/j.14676486.2008.00787.x

Lincoln, Y.S., Guba, E.G., 1985. Naturalistic Inquiry. SAGE Publications, Newbury Park, California. Ludwig, F., 2015. Overview of Market Development in the Electrified Bus Industry with focus on Germany, 1 April to 30 June 2015, Unpublished report (Studienarbeit). Braunchweig, Germany, Linköping University-Sweden.

Markard, J., Raven, R., Truffer, B., 2012. Sustainability transitions: An emerging field of research and its prospects. Research Policy 41, 955-967. doi:10.1016/j.respol.2012.02.013

Meyer, A.D., Gaba, V., Colwell, K.A., 2005. Organizing far from equilibrium: Nonlinear change in organizational fields. Organ Sci. 16, 456-473. doi:10.1287/orsc.1050.0135

Möllering, G., 2010. Collective Market-making Efforts at an Engineering Conference. MPIfG.

Ou, X., Zhang, X., Chang, S., 2010. Alternative fuel buses currently in use in China: Life-cycle fossil energy use, GHG emissions and policy recommendations. Energy Policy 38, 406-418. doi:10.1016/j.enpol.2009.09.031

Raven, R.P.J.M., Heiskanen, E., Lovio, R., Hodson, M., Brohmann, B., 2008. The Contribution of Local Experiments and Negotiation Processes to Field-Level Learning in Emerging (Niche) Technologies Meta-Analysis of 27 New Energy Projects in Europe. Bulletin of Science Technology \& Society 28, 464-477. doi:10.1177/0270467608317523

Raven, R.P.J.M., Verbong, G.P.J., Schilpzand, W.F., Witkamp, M.J., 2011. Translation mechanisms in socio-technical niches: a case study of Dutch river management. Technology Analysis \& Strategic Management 23, 1063-1078. doi:10.1080/09537325.2011.621305

Rip, A., Kemp, R., 1998. Technological Change, in: In: Rayner, S., Malone, E.L. (Eds), Human Choice and Climate Change, Vol. 2. Pp. 327-399. Battelle Press, Columbus, OH.

Rode, P., Floater, G., Thomopoulos, N., Docherty, J., Schwinger, P., Mahendra, A., Fang, W., 2014. Accessibility in cities: transport and urban form [WWW Document]. URL http://Isecities.net/publications/reports/the-new-climate-economy-report/?/ (accessed 4.26.16).

Rotmans, J., Kemp, R., Asselt, M. van, 2001. More evolution than revolution: transition management in public policy. foresight 3, 15-31. doi:10.1108/14636680110803003

Ruef, A., Markard, J., 2010. What happens after a hype? How changing expectations affected innovation activities in the case of stationary fuel cells. Technology Analysis \& Strategic Management 22, 317-338. doi:10.1080/09537321003647354 
Schot, J., Geels, F.W., 2008. Strategic niche management and sustainable innovation journeys: theory, findings, research agenda, and policy. Technology Analysis \&amp; Strategic Management 20, 537-554. doi:10.1080/09537320802292651

Schuldt, N., Bathelt, H., 2011. International Trade Fairs and Global Buzz. Part II: Practices of Global Buzz. European Planning Studies 19, 1-22. doi:10.1080/09654313.2011.530390

Schwandt, T.A., Halpern, E.S., 1988. Linking Auditing and Meta-Evaluation: Enhancing Quality in Applied Research. SAGE Publications, Newbury Park, Calif.

Sengers, F., Raven, R., 2015. Toward a spatial perspective on niche development: The case of Bus Rapid Transit. Environmental Innovation and Societal Transitions 17, 166-182. doi:10.1016/j.eist.2014.12.003

Smink, M., Negro, S.O., Niesten, E., Hekkert, M.P., 2015. How mismatching institutional logics hinder niche-regime interaction and how boundary spanners intervene. Technological Forecasting and Social Change 100, 225-237. doi:10.1016/j.techfore.2015.07.004

Smith, A., 2007. Translating Sustainabilities between Green Niches and Socio-Technical Regimes. Technology Analysis \& Strategic Management 19, 427-450. doi:10.1080/09537320701403334

Smith, A., Raven, R., 2012. What is protective space? Reconsidering niches in transitions to sustainability. Research Policy, Special Section on Sustainability Transitions 41, 10251036. doi:10.1016/j.respol.2011.12.012

Truffer, B., Coenen, L., 2012. Environmental Innovation and Sustainability Transitions in Regional Studies. Regional Studies 46, 1-21. doi:10.1080/00343404.2012.646164

UITP, 2015. International Association of Public Transport [WWW Document]. UITP. URL http://www.uitp.org/all-projects (accessed 11.22.15).

UITP-PTX2, 2014. International Association of Public Transport (UITP), Strategy for public transport [WWW Document]. UITP. URL http://www.uitp.org/strategy-public-transport (accessed 4.26.16).

UNEP, 2009. United Nations Environment Programme, Cities and Climate Change, IEA Training Manual Volume Two (No. Job Number: DEW/1251/NA, ISBN: 978-92-807-3072-2).

Van Audenhove, F.-J., Korniichuk, O., Dauby, L., Pourbaix, J., 2014. The Future of Urban Mobility 2.0: Imperatives to Shape Extended Mobility Ecosystems of Tomorrow. Arthur D. Little, available: https://trid.trb.org/view.aspx?id=1317253 [accessed 26 Apr 2016].

Verbong, G., Geels, F.W., Raven, R., 2008. Multi-niche analysis of dynamics and policies in Dutch renewable energy innovation journeys (1970-2006): hype-cycles, closed networks and technology-focused learning. Technology Analysis \& Strategic Management 20, 555573. doi:10.1080/09537320802292719

Yin, R.K., 2013. Case Study Research: Design and Methods. SAGE Publications, London.

ZeEUS, 2016. Zero Emission Urban Bus System [WWW Document]. URL http://zeeus.eu/ (accessed 5.19.16).

\section{FULL REFERENCE TO THE ITEMS IN TABLE 2:}

Busworld (2015) 'Busworld international exhibition, (Field study 16-18 October, KortrijkBelgium)', available: http://kortrijk.busworld.org/.

IAA (2014) 'The 65th International Motor Show for Commercial Vehicles in Germany, (Field study 26-28 September 2014, Hanover)', available: http://archiv.iaa.de/2014/en/.

UITP (2015) 'UITP World Congress and Exhibition (Field study 8-10 June 2015, MilanItaly)', available: http://www.uitpmilan2015.org/. 


\section{APPENDIX1. List of interviews}

\begin{tabular}{|c|c|c|c|c|}
\hline $\begin{array}{l}\text { Organization } \\
\text { alphabetic order }\end{array}$ & Respondent's role & Venue & Date & Topic \\
\hline Bozankaya & Development Manager & UITP & June, 2015 & Full electric \\
\hline$B Y D$ & $\begin{array}{l}\text { Country Manager Europe } \\
\text { Deputy Sales Director EU/Nordic }\end{array}$ & $\begin{array}{l}\text { UITP } \\
\text { BusWorld }\end{array}$ & $\begin{array}{l}\text { June, } 2015 \\
\text { Oct, } 2015 \\
\end{array}$ & $\begin{array}{l}\text { Full electric/ Double } \\
\text { decker }\end{array}$ \\
\hline$D A F$ & Exhibitor & $\begin{array}{l}\text { UITP } \\
\text { BusWorld }\end{array}$ & $\begin{array}{l}\text { June, } 2015 \\
\text { Oct, } 2015 \\
\end{array}$ & Advanced diesel \\
\hline Daimler & $\begin{array}{l}\text { EvoBus Marketing Information } \\
\text { department }\end{array}$ & $\begin{array}{l}\text { UITP } \\
\text { BusWorld }\end{array}$ & $\begin{array}{l}\text { June, } 2015 \\
\text { Oct, } 2015 \\
\end{array}$ & $\begin{array}{l}\text { CNG, electric, } \\
\text { Fuel-cell }\end{array}$ \\
\hline EBUSCO & $\mathrm{COO}$ & UITP & June, 2015 & Full electric \\
\hline$E K O V A$ & Production Technologist & BusWorld & Oct, 2015 & Full electric \\
\hline FIAT/IVECO & Exhibitor & $\begin{array}{l}\text { UITP } \\
\text { BusWorld }\end{array}$ & $\begin{array}{l}\text { June, } 2015 \\
\text { Oct, } 2015 \\
\end{array}$ & Advanced diesel/CNG \\
\hline Gépé bus & Electric Vehicles OEM Product Director & UITP & June, 2015 & Full electric \\
\hline $\begin{array}{l}\text { Golden } \\
\text { Dragon }\end{array}$ & Exhibitor & BusWorld & Oct, 2015 & Diesel \\
\hline $\begin{array}{l}\text { Hamburger } \\
\text { Hochbahn }\end{array}$ & Member of the board & Hamburg & Oct, 2015 & $\begin{array}{l}\text { Hybrid, Full electric, } \\
\text { Fuel-cell }\end{array}$ \\
\hline Hybricon & $\mathrm{CFO} /$ Sales/Production/Technicians & Umeå & & Full electric \\
\hline HySolutions & Managing Director & Hamburg & Oct, 2015 & $\begin{array}{l}\text { Hybrid, Full electric, } \\
\text { Fuel-cell }\end{array}$ \\
\hline$I N D C A R$ & Sales Area Manager & BusWorld & Oct, 2015 & Diesel \\
\hline$I R I Z A R$ & Sales director & UITP & June, 2015 & Full electric \\
\hline$I S U Z U$ & Export Specialist & BusWorld & Oct, 2015 & Diesel, CNG \\
\hline$K A R S A N$ & Sales agent & UITP & June, 2015 & Diesel, CNG \\
\hline King Long & Exhibitor & BusWorld & Oct, 2015 & $\begin{array}{l}\text { Parallel hybrid, } \\
\text { Power-split hybrid }\end{array}$ \\
\hline Linkker & Sales Director Nordic & Nordic Bus Initiative & Sep, 2015 & Full electric \\
\hline$M A N$ & Project manager sales (Bus \& Coach) & $\begin{array}{l}\text { UITP } \\
\text { BusWorld }\end{array}$ & $\begin{array}{l}\text { June, } 2015 \\
\text { Oct, } 2015 \\
\end{array}$ & Diesel, CNG, Electric \\
\hline OTOKAR & Sales agent & UITP & June, 2015 & $\begin{array}{l}\text { Diesel, CNG, Hybrid, } \\
\text { Electric }\end{array}$ \\
\hline Scania & $\begin{array}{l}\text { Project Sales Manager } \\
\text { Product Manager BRT }\end{array}$ & $\begin{array}{l}\text { UITP } \\
\text { BusWorld }\end{array}$ & $\begin{array}{l}\text { June, } 2015 \\
\text { Oct, 2015 }\end{array}$ & CNG, Electric \\
\hline Solaris & $\begin{array}{l}\text { Senior Area Manager } \\
\text { Vice Director Public Relations } \\
\text { Sale Manager for Sweden }\end{array}$ & $\begin{array}{l}\text { IAA } \\
\text { UITP } \\
\text { BusWorld }\end{array}$ & $\begin{array}{l}\text { Sep. } 2014 \\
\text { June, } 2015 \\
\text { Oct, } 2015\end{array}$ & Electric, Hybrid \\
\hline TEMSA & $\begin{array}{l}\text { MD German, Sales Italy/Spain } \\
\text { Marketing \& PR Germany }\end{array}$ & UITP & June, 2015 & $\begin{array}{l}\text { Diesel, } \\
\text { Full electric } \\
\end{array}$ \\
\hline $\begin{array}{l}\text { Umeå } \\
\text { Municipality }\end{array}$ & Public Transport Manager & Umeå kommun & Feb, 2016 & Full electric \\
\hline VanHool & Communicating manager & $\begin{array}{l}\text { UITP } \\
\text { BusWorld }\end{array}$ & $\begin{array}{l}\text { June, } 2015 \\
\text { Oct, } 2015 \\
\end{array}$ & $\begin{array}{l}\text { Diesel, Hybrid, } \\
\text { Full electric }\end{array}$ \\
\hline$V D L$ & $\begin{array}{l}\text { Sales Operations } \\
\text { Commercial Project Manager }\end{array}$ & $\begin{array}{l}\text { UITP } \\
\text { BusWorld } \\
\end{array}$ & $\begin{array}{l}\text { June, } 2015 \\
\text { Oct, } 2015 \\
\end{array}$ & Series hybrid, Electric \\
\hline Volvo & $\begin{array}{l}\text { Former CEO } \\
\text { Public Affairs Manager } \\
\text { Project representative }\end{array}$ & $\begin{array}{l}\text { Gothenburg } \\
\text { Hamburg innovation line } \\
\text { ElectriCity }\end{array}$ & & $\begin{array}{l}\text { Hybrid, } \\
\text { Full Electric }\end{array}$ \\
\hline ZeEUS & EU Projects Manager & $\begin{array}{l}\text { UITP } \\
\text { Online interview } \\
\end{array}$ & $\begin{array}{l}\text { June, } 2015 \\
\text { Nov, } 2015 \\
\end{array}$ & $\begin{array}{l}\text { Hybrid, } \\
\text { Full electric }\end{array}$ \\
\hline Ziehl Abeeg & Exhibitor/ Technician & BusWorld & Oct, 2015 & Full electric \\
\hline
\end{tabular}




\section{APPENDIX II. Tables and figures}

Table 1 Primary sources of data

\begin{tabular}{|c|c|c|}
\hline Field Configuring Events & Date & Location \\
\hline $\begin{array}{l}\text { IAA Internationale Automobil Ausstellung } \\
\text { (Commercial Vehicles) }\end{array}$ & Sep, 2014 & Hanover, Germany \\
\hline UITP world congress \& exhibition & Jun, 2015 & Milan, Italy \\
\hline Nordic electric bus initiative & Sep, 2015 & Gothenburg, Sweden \\
\hline Busworld exhibition & Oct, 2015 & Kortrijk, Belgium \\
\hline Transport forum & Jan, 2016 & Linköping, Sweden \\
\hline Field visits to electric bus projects & Date & Location \\
\hline Hamburg innovation line & Sep, 2015 & Hamburg, Germany \\
\hline ElectriCity project & Jun/Sep 2015 & Gothenburg, Sweden \\
\hline Umeå airport shuttle electric bus & Feb, 2016 & Umeå, Sweden \\
\hline Interviews with bus manufacturers \& PTAs & Date & Location \\
\hline $\begin{array}{l}\text { UITP representative \& coordinating body for } \\
\text { advancing powertrain technologies (ZeEUS) }\end{array}$ & Nov, 2015 & Online from Brussels \\
\hline Hamburger Hochbahn AG & Sep, 2015 & Hamburg, Germany \\
\hline Umeå municipality & Feb. 2016 & Umeå, Sweden \\
\hline $\begin{array}{l}\text { Company representatives from: } \\
\text { Scania, Volvo, Daimler, MAN, BYD, Solaris, Ebusco, } \\
\text { VDL, Irizar, VanHool, Bozankaya (Sileo), Hybricon }\end{array}$ & 2015- 2016 & $\begin{array}{l}\text { FCEs and Field visits } \\
\text { (see Appendix 1) }\end{array}$ \\
\hline
\end{tabular}


Table 2, Manufacturers promoting electric city buses at major European exhibitions

\begin{tabular}{|c|c|c|c|c|c|}
\hline Category & Firm & Powertrain & Charging technology & $\begin{array}{l}\text { Distance } \\
\text { range }\end{array}$ & $\begin{array}{l}\text { Exhibition / } \\
\text { Trade fair }\end{array}$ \\
\hline \multirow{3}{*}{ Newcomers } & BYD & Full electric & $\begin{array}{l}\text { Slow-charging } \\
\text { Conductive or Inductive } \\
\text { (under development) }\end{array}$ & $\begin{array}{l}1 \mathrm{KM} / \mathrm{KWh} \\
260 K W h=> \\
260 K M\end{array}$ & $\begin{array}{l}\text { UITP } 2015 \\
\text { Busworld } 2015\end{array}$ \\
\hline & Ebusco & Full electric & $\begin{array}{l}\text { Slow-charging } \\
\text { Conductive }\end{array}$ & $\begin{array}{l}300 \mathrm{KM} \text { per } \\
\text { charge in city } \\
\text { traffic }\end{array}$ & $\begin{array}{l}\text { IAA } 2014 \\
\text { UITP } 2015 \\
\text { Busworld } 2015\end{array}$ \\
\hline & Hybricon & $\begin{array}{l}\text { Full electric with } \\
\text { optional range } \\
\text { extender }\end{array}$ & $\begin{array}{l}\text { Fast-charging } \\
\text { Conductive: inverted } \\
\text { pantograph } \\
\text { (can also offer slow- } \\
\text { charging) }\end{array}$ & $\begin{array}{l}20 \mathrm{KM} \text { or } \\
1 \mathrm{hr} \text { drive }\end{array}$ & Busworld 2015 \\
\hline $\begin{array}{l}\text { Integrated bus } \\
\text { and truck } \\
\text { manufacturers }\end{array}$ & Volvo & $\begin{array}{l}\text { Plug-in hybrid } \\
\text { (Full electric } \\
\text { available from } \\
\text { 2017) }\end{array}$ & $\begin{array}{l}\text { Fast-charging } \\
\text { Conductive: inverted } \\
\text { pantograph }\end{array}$ & 8-12 KM & $\begin{array}{l}\text { IAA } 2014 \\
\text { UITP } 2015 \\
\text { Busworld } 2015\end{array}$ \\
\hline \multirow{6}{*}{$\begin{array}{l}\text { Specialized bus } \\
\text { manufacturers }\end{array}$} & $\begin{array}{l}\text { Bozankaya } \\
\text { (Sileo) }\end{array}$ & Full electric & $\begin{array}{l}\text { Slow-charging } \\
\text { Sileo specific conductive } \\
\text { (DCM) }\end{array}$ & $\begin{array}{l}200 \mathrm{KM} / 300 \\
\mathrm{KM}\end{array}$ & $\begin{array}{l}\text { IAA } 2014 \\
\text { UITP } 2015 \\
\text { Busworld } 2015\end{array}$ \\
\hline & Ekova & Full electric & $\begin{array}{l}\text { Slow or fast-charging } \\
\text { Conductive: plug or arm }\end{array}$ & $\begin{array}{l}\text { Depending on } \\
\text { technology \& } \\
\text { infrastructure }\end{array}$ & Busworld 2015 \\
\hline & Irizar & Full electric & $\begin{array}{l}\text { Slow-charging } \\
\text { Conductive: standard combo }\end{array}$ & $180 \mathrm{KM}$ or $16 \mathrm{hrs}$ & $\begin{array}{l}\text { UITP } 2015 \\
\text { Busworld } 2015\end{array}$ \\
\hline & Solaris & Full electric & $\begin{array}{l}\text { Slow or fast-charging } \\
\text { Conductive or inductive }\end{array}$ & $\begin{array}{l}\text { Depending on } \\
\text { technology \& } \\
\text { infrastructure }\end{array}$ & $\begin{array}{l}\text { IAA } 2014 \\
\text { UITP } 2015 \\
\text { Busworld } 2015\end{array}$ \\
\hline & VanHool & $\begin{array}{l}\text { Full electric } \\
\text { (multi-propulsion } \\
\text { platform) }\end{array}$ & $\begin{array}{l}\text { Slow or fast-charging } \\
\text { Conductive or inductive }\end{array}$ & $\begin{array}{l}\text { Depending on } \\
\text { technology \& } \\
\text { infrastructure }\end{array}$ & $\begin{array}{l}\text { UITP } 2015 \\
\text { Busworld } 2015\end{array}$ \\
\hline & VDL & $\begin{array}{l}\text { Full electric with } \\
\text { optional range } \\
\text { extender }\end{array}$ & $\begin{array}{l}\text { Slow or fast-charging } \\
\text { Conductive or inductive }\end{array}$ & $\begin{array}{l}\text { Depending on } \\
\text { technology \& } \\
\text { infrastructure }\end{array}$ & $\begin{array}{l}\text { IAA } 2014 \\
\text { UITP } 2015 \\
\text { Busworld } 2015\end{array}$ \\
\hline
\end{tabular}



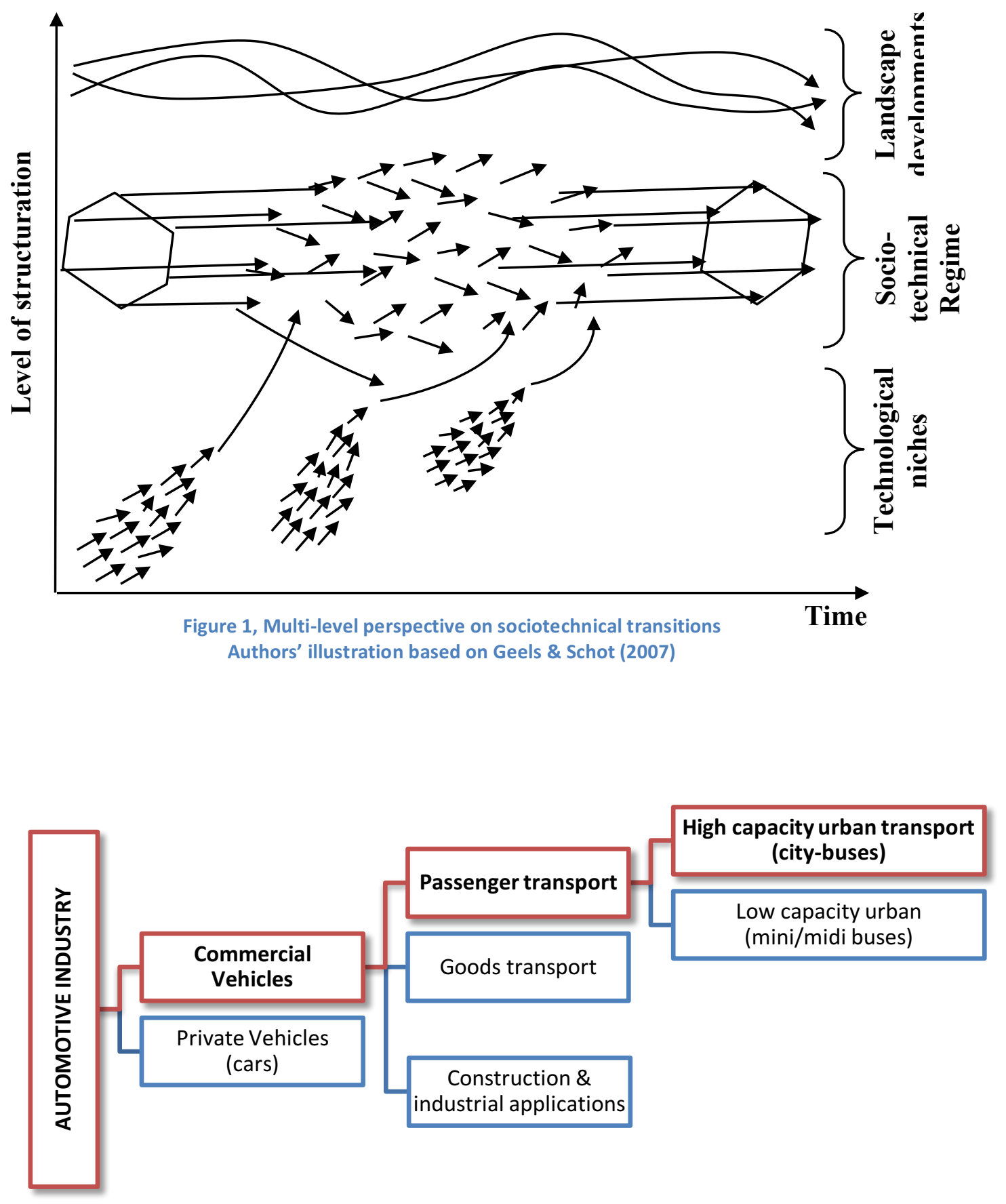

Figure 2, Breaking down of the automotive industry into different segments 